\title{
Students' Emotional Intelligence and Self-efficacy towards Their Academic Performance: A Survey Study on Public Higher Learning Institution
}

\author{
Abdul Rashid Abdul Aziz*, Shahirah Sulaiman, Nor Hamizah Ab Razak \\ Faculty of Leadership and Management, Universiti Sains Islam Malaysia, 71800 Nilai, Negeri Sembilan, Malaysia
}

Received September 30, 2020; Revised November 1, 2020; Accepted November 7, 2020

\section{Cite This Paper in the following Citation Styles}

(a): [1] Abdul Rashid Abdul Aziz, Shahirah Sulaiman, Nor Hamizah Ab Razak, "Students' Emotional Intelligence and Self-efficacy towards Their Academic Performance: A Survey Study on Public Higher Learning Institution," Universal Journal of Educational Research, Vol. 8, No. 11C, pp. 129 - 135, 2020. DOI: 10.13189/ujer.2020.082315.

(b): Abdul Rashid Abdul Aziz, Shahirah Sulaiman, Nor Hamizah Ab Razak (2020). Students' Emotional Intelligence and Self-efficacy towards Their Academic Performance: A Survey Study on Public Higher Learning Institution. Universal Journal of Educational Research, 8(11C), 129 - 135. DOI: 10.13189/ujer.2020.082315.

Copyright $@ 2020$ by authors, all rights reserved. Authors agree that this article remains permanently open access under the terms of the Creative Commons Attribution License 4.0 International License

\begin{abstract}
Learning in higher institution is a challenging situation. Students may adapt well to the new academic environment or might experience failure in coping with the demand of real-life learning. In most of the time, they would be physically and emotionally drained. Hence, this study investigated students in public higher learning institution on managing their emotional intelligence and self-efficacy towards their academic performance in such setting. A total of 150 valid questionnaires were collected in a public university in Selangor, Malaysia using purposive sampling method. The Academic Self-Efficacy Scale (ASE) and Emotional Quotient Inventory (EQ-i) instruments were used. In order to achieve the study's objective, the data were analyzed using Statistical Package for Social Studies (SPSS) for its descriptive analyses, t-test and Pearson correlation analyses. It was found that there is a significant relationship between students' emotional intelligence and academic performance, self-efficacy based on academic performance and there is a relationship between students' emotional intelligence and academic self-efficacy. It is vital to investigate this area of study as it would affect this tertiary students' performance in their studying years.
\end{abstract}

Keywords Emotional Intelligence, Self-efficacy, Academic Performance

\section{Introduction}

Malaysia's higher learning institution system has grown rapidly where there has been a significant increase in students' enrollment, global recognition and a sharp growth in the number of international students. As another developed country, Malaysia also prioritizes education as it can make a significant contribution to socio-economic development as well as human capital development. To date, in Malaysia there are more than 500 institutions of higher learning including public, private institutions and even community colleges. Since the inception of its first university in 1905, Malaysia now has 20 public universities, 32 private universities and university colleges, 4 branch campuses of international universities, 21 polytechnics, 37 public community colleges and 485 private colleges. Malaysia's higher education progress has been impressive, but with the increasing number of global competitions, Malaysia needs to transform its higher education sector.

Reforms have begun with the implementation of the National Higher Education Strategic Plan as the Ministry is aware that the National education system needs to be further enhanced in order to remain competitive in line with global trends. Thus, various efforts and strategies have been planned and implemented by higher education institutions to produce quality and excellent graduates in terms of physical, emotional, spiritual and intellectual 
factors. It is vital to take a look on one's emotional state especially among these students as it forms their attitudes and personalities in life. Emotions are defined as a condition experience by humans that develop several changes in physiological, self and psychological processes (Mohmood Nazar Mohamad, 1992). Unbalance emotional state would affect students' performance while studying if they are in a challenging situation. In addition, emotional development among students is the core value of student development to academic achievement and student preservation in their studying years (Low \& Nelson, 2009). According to Emang et al. (2014), it may be a common issue but particularly it is essential for the field of education.

In addition, there have been many studies related to social and emotional factors as the important role of determining students' academic excellence. According to Mustafa et al (2016), he explained that there is a relationship between emotional intelligence and academic achievement those students who have high scores in emotional intelligence show better performance in academic achievement. While, Goleman (1998) stated that emotional intelligence refers to the capacity for recognizing our own feelings and those of others, for motivating ourselves, and for managing emotions well in ourselves and in our relationships. Goleman (1995) further reiterates that our thinking is always influenced by our emotions. It denotes that students who are chronically sad or angry or even anxious find it hard for them to concentrate and to learn. Snyder as well (1991) did a study amongst freshmen as they entered college. He found that those who scored higher on hope (emotional intelligence) had higher grades at the end of the year and that hope was a better predictor of good grades. Thus, Basan \& Omar (2014) stressed the need to focus on emotional intelligence and its role in improving student academic achievement.

Especially, most studies have found that the issues faced by students are a factor in the decline in academic achievement (Add, 2019; Irfan \& Shabana 2012). Some studies explained that among the issues that are often experienced by students, especially university students such as issues of stress, finance, drug abuse, family and so on (Lin 2015). Malaysian educators are worried about low academic achievement among students that many are lack of self-efficacy. The University Utara Malaysia scenario showed that most of the students obtained low academic achievement due to several reasons such as lack of motivation, low self-efficacy and other reasons. This is crucial as nevertheless, some studies have also found that academic self-efficacy also contributes to students' academic excellence (Richardson et al. 2012; Honicke \& Broadbent 2016). Academic self efficacy refers to students' belief and confidence that they will successfully achieve a specified level in academic tasks or achieve certain academic goals (Pajares, 1996). It was found that students in higher learning institutions who have high self-efficacy are confident in their ability to perform well academically. This, in turn, influenced their performance as in comparison; students who are lack of self-efficacy may not perform well in academic compared to students who have higher academic expectations. Self-efficacy remained significant as a measure of academic ability.

In order to grasp a clearer view on such area, this study would like to investigate the aforementioned topic especially there is not much study discusses on it especially in Malaysia's higher learning institution setting. Thus, this study will be a primary reference in understanding the relative connection of students' emotional intelligence, self-efficacy and academic performance at tertiary level accordingly.

\section{Objectives}

1) To measure the level of academic performance among students.

2) To examine differences between emotional intelligence \& academic self-efficacy based on academic performance

3) To identify the relation between emotional intelligence and academic self-efficacy.

\section{Literature Review}

Emotional intelligence is an increasingly popular concern and topic that plays an enormous part in one's success. As early as the 1900's until around 1970's, Mayer (2001) stated that an interest in intelligence testing was solely focused on cognition and the study on emotions focused on clarification as 'chicken-and-egg' problem of which happens first: physiological reaction, or emotion. Apart from that, studies within emotions research were also focused on whether emotions were universal or culturally determined and idiosyncratic. Goleman (1996), Dulewicz and Higgs (2000) provide support for this proposition that the combination of emotional intelligence and intellectual quality (IQ) is a more powerful predictor of success that either measures alone. For example, in an academic setting, a study done by Marquez et al. (2006) among students, it was found that emotional intelligence scores are correlated with academic achievement after controlling for general intelligent. In others studies, correlation between emotional intelligence showed a great range from $r=0.20$ to 0.25 for higher learning institutions students (Bracket \& Mayer, 2003; Jaleel \& Verghis, 2017).

Grace (2012) claimed that emotional intelligence is crucial to study and imperative to one's success as its significant positive relationships were established between students' academic achievement as well. It denotes that students who have high level of emotional intelligence traits tend to adapt better to social and interpersonal environment with others. Also, these students have better 
time management in comparison to students who have low emotional intelligence as these opposite students would have harmful behavior traits (Pau, et al., 2004). It is important to observe students in higher learning institutions' emotional intelligence as according to Ghosh and Gill (2003), students who possess high emotional intelligence are more confident, fast learners, cheerful and could manage their emotions accordingly. Kamassi, Ahmed et al. (2019) signifies that emotional intelligence ability is essential in higher education context. This is seconded by previous study (Shi \& Wang, 2007; Salami, 2010; Kumar \& Muniandy, 2012; Fall, et al., 2013) that emotional intelligence is highly acknowledged among higher education students as well.

In Malaysia, such situation is a concern as well as Malaysia has profoundly developed towards a reputable educational transformation process to achieve greater socio-economic progress and human capital development. Hilaluddin Johan Ariffin (2003) suggested that emotional intelligence play significant roles in student's academic achievements. The influence of emotional intelligence on popular culture and the academic community has been rapid and widespread (Emmerling \& Goleman, 2003). Vela (2003) and Stottlemyer (2002) also claimed that there were significant correlations between emotional intelligence skills and academic achievement. The domains of emotional intelligence, which are self-awareness and empathy, were significantly related to academic achievement as seconded by Norhayati Ahmad's study (2003) among third semester in Diploma of Teaching courses students. Especially, emotional intelligence would affect students' achievement and performance whether towards positive or negative in their learning experience that would be a worrisome (Salovery \& Mayer, 1990).

Besides that, most of the studies claimed that self-efficacy is a good predictor of one's real performance. Self-efficacy denotes when one needs to react to such situation of an expected manner with appropriate skills, knowledge and attitudes (Savas, Bozgeyik \& Eser, 2014). In congruence with such claim, Ngui and Lay (2020) stated that personal attributes as emotional intelligence, self-efficacy and subjective well-being would stimulate one's resilience in managing any tense situation. This is supported by previous study that as well proven there is a connection between these idiosyncratic (Abebe \& HaileMariam, 2011; Hong, 2012; Koydemir \& Schlutz, 2012; Lane \& Wilson, 2011; Maher et al., 2012; Mapfumo, et al., 2012; Windle, Bennett, \& Noyes, 2011). Furthermore, academic self-efficacy also contributes to students' academic excellence (Richardson et al. 2012; Honicke \& Broadbent 2016). For example, in one study carried out by Bandura, Adams \& Beyer (1977) showed that there is a strong relationship between self-efficacy judgements and real performance.

It has shown that these idiosyncratic are inter-related with one and another. One's emotional intelligence would possibly be different as it relies on their self-efficacy in managing the new academic life personally and socially. This is vital to investigate as it would affect students' performance in their studying years. Especially, in Malaysia there is a minimal study exploring on this area. Hence, this study aims to identify the relationship between emotional intelligence and self-efficacy to students' academic performance among Malaysia's public higher learning institutions.

\section{Methodology}

This is a quantitative research and it involves descriptive and inferential analysis. This study using survey design consists of 150 university students. This study involved students in a public university in Selangor, Malaysia who are selected using purposive sampling method in order to determine low and high academic achiever. The populations of this study are designated as a full-time student which comprising of 16 courses. The Academic Self-Efficacy Scale (ASE) is used to assess academic self-efficacy among students. The inventory created by Owen and Froman (1988). The scale was developed using three university faculty members who devised a pool of what they considered to be routine academic behaviors for college students. The inventory consists of 33 items without hierarchical composition, and participants will be asked to respond using a 5-point Likert-type scale ranging from 1 , or "very little" to 5 , or "quite a lot." The emotional intelligence among students measured using Emotional Quotient Inventory (EQ-i) which consists of 133 items. EQ-i instrument measured using five-point Likert scales along with 15 subscales. This inventory was developed by Reuven Bar-On (Bar-On: 1996, revised 2002). Whereby, academic performance in this study referred to student's achievement in examination. Meanwhile, students also grouped according to their cumulative grade point average (CGPA) as high achievers (3.50 and above) and low achievers (below 2.65). The data collected were analyzed descriptively to measure academic performance of samples. Independent sample t-tests were used to measure differences in emotional intelligence and academic self-efficacy between low-and high-achieving groups. Correlation analysis was also done to determine the relationship between emotional intelligence and academic self-efficacy.

\section{Result and Discussion}

The collected data were analysed using Statistical Package for Social Studies (SPSS) version 23. Categorical variables were presented as frequency (n) and percentage (\%). 
Table 1. The distribution of samples across demographic characteristics

\begin{tabular}{cccc}
\hline $\begin{array}{c}\text { Demographic } \\
\text { variable }\end{array}$ & Category & Frequency & Percent \\
\hline Gender & Male & 59 & 39 \\
& Female & 91 & 61 \\
& Total & 150 & 100 \\
Level of study & First year & 52 & 35.0 \\
& Second year & 55 & 37.0 \\
& Third year & 38 & 25.0 \\
& Others & 5 & 3.0 \\
CGPA & Total & 150 & 100 \\
& 3.50 and & 68 & 45.0 \\
& above & 82 & 55.0 \\
& 2.65 and & 150 & 100 \\
& below & & \\
\hline
\end{tabular}

Table 1 above described the distribution of the respondents in terms of their demographic information. It shows that 35\% came from the first year, 37\% from the second year, $25 \%$ in third year level of study and only $3 \%$ come from others. In addition, this study consists of 59\% male students whereby $91 \%$ of female students. The data collected also indicate that $68 \%$ students were among high achiever while $82 \%$ students were low achiever.

Table 2. The difference between emotional intelligence based on academic performance

\begin{tabular}{cccccc}
\hline $\begin{array}{c}\text { Academic } \\
\text { Performance }\end{array}$ & $\mathrm{N}$ & $\mathrm{M}$ & $\mathrm{SD}$ & $\mathrm{df}$ & $\mathrm{p}$ \\
\hline High achiever & 68 & 425.92 & 41.37 & 98 & \\
Low achiever & 82 & 312.92 & 38.47 & 74.84 & .001 \\
\hline $\mathrm{n}=150$ & & & & & \\
$\mathrm{p}<0.05$ & & & & &
\end{tabular}

The results of independent sample t-test in Table 2 shows a significant difference is encountered between high achiever and low achiever students in terms of their emotional intelligence $(p<0.05=0.001)$. Furthermore, the mean of emotional intelligence for high achiever students $(M=425.92)$ is found higher than that of low achiever students $(M=312.92)$.

Table 3. The difference between academic self-efficacy based on academic performance

\begin{tabular}{lccccc}
\hline $\begin{array}{c}\text { Academic } \\
\text { Performance }\end{array}$ & $\mathrm{N}$ & $\mathrm{M}$ & $\mathrm{SD}$ & $\mathrm{df}$ & $\mathrm{p}$ \\
\hline High achiever & 68 & 4.8962 & 1.035 & 98 & \\
Low achiever & 82 & 2.7767 & 1.938 & 74.84 & 0.000 \\
\hline $\mathrm{n}=150$ & & & & & \\
$\mathrm{p}<0.05$ & & & & &
\end{tabular}

The results of independent sample t-test in Table 3 shows a significant difference is encountered between high achiever and low achiever students in terms of their academic self-efficacy $(\mathrm{p}<0.05=0.000)$. Furthermore, the mean of academic self-efficacy for high achiever students $(M=4.89)$ is found higher than that of low achiever students $(M=2.77)$
Table 4. The difference between sub-scale of academic self-efficacy among students

\begin{tabular}{ccc}
\hline $\begin{array}{c}\text { Domain of Academic } \\
\text { Self Efficacy }\end{array}$ & $\begin{array}{c}\text { High Achiever } \\
\text { Mean }(M)\end{array}$ & $\begin{array}{c}\text { Low Achiever } \\
\text { Mean }(M)\end{array}$ \\
\hline Social Status & 4.32 & 3.12 \\
Cognitive Application & 4.81 & 2.42 \\
Technical Skills & 4.70 & 2.83 \\
Total Mean Score & 4.61 & 2.79 \\
\hline
\end{tabular}

While, the result of Table 4 revealed that there is a significant difference between high achiever and low achiever students in terms of their sub-scale of self-efficacy. The total mean score of high achiever students $(M=4.61)$ is higher in comparison to the total mean score of the low achiever students $(M=2.79)$. Also, the mean of low achiever student's social status $(M=3.12)$ is found higher than the mean of low achiever students' cognitive application $(M=2.42)$.

Table 5. Relationship between emotional intelligence and academic self-efficacy

\begin{tabular}{ccc}
\hline Categories & & $\begin{array}{c}\text { Academic } \\
\text { Self-Efficacy }\end{array}$ \\
\hline $\begin{array}{c}\text { Emotional } \\
\text { Intelligence }\end{array}$ & $\begin{array}{c}\text { Pearson } \\
\text { Correlation } \\
\text { Sig. (2-tailed) }\end{array}$ & $.249 *$ \\
& .000 \\
\hline
\end{tabular}

$\mathrm{n}=150$

In Table 5 above, Pearson Correlation method was used to analyze the relationship between two variables of emotional intelligence and academic self-efficacy. The result revealed that emotional intelligence and academic self-efficacy significantly correlated $\quad(r=0.249$, $\mathrm{p}<0.05=0.000$ ).

From the findings, it reflects that the association between emotional intelligence and academic performance was found to be significant. It is in line with Grace's study (2012) that emotional intelligence has significant positive relationships established between students' academic achievements. Furthermore, there is also a connection between self-efficacy based on academic performance. It was found that, indeed, academic self-efficacy was strongly related to academic performance and adjustment. This is incongruence with Chemers et al. (2001) that claimed students who have high self-efficacy entered higher learning institutions with confidence will perform well academically as well. Meanwhile, students who are lack of self-efficacy might not perform well academically.

In addition, the findings illustrated that there is a significant relationship between sub-scale of self-efficacy among students. From the findings, students' social status, cognitive application and technical skills are significant between one and another among the high and low achievers' students. This is in line with Savas, Bozgeyik \& Eser (2014) statement that one's self-efficacy is determined by their appropriate skills, knowledge and attitudes. Moreover, it was identified that there is a relationship between students' 
emotional intelligence and academic self-efficacy among higher learning institutions students. This current study also indicated that students in the university in Malaysia portrayed a moderate level of academic performance. The findings also found that emotional intelligence and academic self-efficacy were significant predictor of academic performance in university students. Therefore, this result could indicate the significant presence of emotional intelligence and academic self-efficacy effect on the improvement on academic performance in students.

As a result, the findings of this study indicated that the mean of emotional intelligence and academic self-efficacy for high achiever students is found higher than that of low achiever students. The findings sustain the results of another author as Alyami et al (2017). Significant differences have been obtained highlighting the fact that students with high academic performance perceive themselves as having high levels of emotional intelligence, being able to understand and accurately perceive their own emotions and utilize emotions in social environments and also efficacious in think highly of their capabilities. Also, the result of this study explained that higher achiever tends to perceive efficacy in accomplishing academic behaviors that imply social status, cognitive application and technical skill, as compared to low achiever.

These results are easily explained by when students need to bear their emotional intelligence competencies, such as the ability to organize feelings, problem solving, intrapersonal and interpersonal skills, which are closely related to academic success. For example, a student who has very good skills in emotional management can use these skills to cope with stress and anxiety associated with tests and exams. Furthermore, the ability to demonstrate interpersonal skills can assist students to get academic help from teachers, peers and resource persons. In addition, those with high levels of self-efficacy tend to rely on themselves when facing complex problems to find a way out of the problem, as well as being patient during the process, making more effort, and lasting longer to overcome challenges. Thus, it seems that self-efficacy is one of the most important factors in students' academic success.

The findings of this study, however, contradicts those of Al-Ghamdi (2014) and Sahinidis et. al (2016) who found that emotional intelligence was not significantly associated with academic achievement. One explanation for this apparent contradiction may be due different aspect of investigation regarding emotional intelligence as it has many areas and components. While, Khan et al (2013) and Neuville et al. (2007) found academic self-efficacy do not contribute to the academic achievement. However, this result due to the used of global attributes rather than specific measures of academic self-efficacy (Honicke \&Broadbent 2016).

In response to the last objective, that investigated the relationship between emotional intelligence and academic self-efficacy, the findings revealed emotional intelligence and academic self-efficacy significantly are correlated. This result was in line with a study by Hen \& Goroshit (2014) reported a significant correlation between emotional intelligence and academic self-efficacy. This has again strengthened previous findings concerning emotional intelligence and academic self-efficacy by Belanger et al. (2007) as indicated that although students' emotional intelligence was not directly linked to academic success, students with higher levels of emotional intelligence had more self-efficacy and that in turn enhanced their academic performance.

\section{Conclusions}

Students at higher learning institution face distress of new learning environment and demand as they have to put their various knowledge and skills into practice that they do not experience much earlier. Students need to adjust such situation by managing it appropriately as it is vital to their positive emotional development. Their emotional intelligence would possibly be different as it relies on their self-efficacy. This is because it will affect them personally and socially in achieving academic success that facilitated their learning experience. Significantly, emotional intelligence is crucial to students' academic success as its significant positive relationships are established as reflected in the present study as well as previous related works. In addition, self-efficacy and emotional intelligence are two personality traits that have a complementary relationship as well.

The implication of this study is that there is a need to enhance academic success among students by designing training modules or program that focused on the development of emotional intelligence and academic self-efficacy in order to slightly enhance their academic achievement in their studying years. Especially, this would be in line with the Malaysia' National education system that urges to be further enhanced in order to remain competitive in line with global trends. On top of that, individual who have high self-efficacy would think highly of their capabilities which influence the initiation, intensity and persistence of behavior. These traits are important for students at such setting to embrace and possess. It is vital as emotional development among students is the core value of students' academic development. Therefore, it is necessary for students in higher learning institutions to know how to cope with such challenging situatons. In brief, further study can be conducted to see closer relation between emotional intelligence, academic self-efficacy and academic performance among students. 


\section{REFERENCES}

[1] Abebe, S., \& HaileMariam, A. (2011). Teacher stressors and potential remedies from pre-service teachers' and cooperating teachers. Eastern Education Journal, 40(1), 6474.

[2] Alan Carr (2004). Positive Psychology; the science of happiness and human strengths. New York: Brunner-Routledge.

[3] Al-Ghamdi, F. (2014). The role of trait emotional intelligence in individual performance: A descriptive study in Albaha University, Saudi Arabia. Journal of Service Science and Management, 7: 361-367.

[4] Alyami M, Melyani Z, Al Johani A, Ullah E, Alyami H, Sundram F, (2017) The impact of self-esteem, academic self-efficacy and perceived stress on academic performance: a cross-sectional study of Saudi psychology students. Eur J Educ Sci (EJES), 4(3):51-68.

[5] Bandura, A. (1997). Sel-Efficacy: Toward a unifying theory of behavioural change. Psychological Review, 84, 191-215.

[6] Bandura, A., Adams, N. E., \& Beyer, J. (1977). Cognitive processes mediating behavioural change. Journal of personality and social psychology, 35, 125-139.

[7] Bar-On, R. (1996). The emotional quotient inventory: A test of emotional intelligence. Toronto, Canada: Multi-Health Systems, Inc.

[8] Bassam Yousef Ibrahim Banat \& Omar Rimawi. (2014). The impact of emotional intelligence on academic achievement: A case study of Al- Quds University students. International Humanities Studies, 1(2).

[9] Bracket, M. A., \& Mayer, J.D. (2003). Convergent, discriminant and incremental validity of competing model of measures of emotional intelligence. Personality and social psychology Bulletin, 29(9), 1-12.

[10] Bradberry, T. \& Greaves, J. (2001-2006). Emotional intelligence appraisal: There is more than IQ, San Diego, CA: Talent Smart Inc.

[11] Chemers, M. M., Hu, L., \& Garcia, B. F. (2001). Academic self- efficacy and first-year college student performance and adjustment. Journal of Educational Psychology, 93(1), $55-64$.

[12] Dagdag, J. D., Cuizon, H. G., \& Bete, A. O. (2019). College students' problems and their link to academic performance: Basis for needs-driven student programs. Journal of Research, Policy \& Practice of Teachers and Teacher Education, 9(2), 54-65.

[13] Emang, S., Azam, N. H., Entigar, S. G., \& Ramli, N. D. (2014). The Relationship between Emotional Intelligence and Academic Achievement: A Study on Government Transformation Programme (GTP) at Secondary Schools in Rural Areas, Ulu Baram Sarawak. WEI International Academic Conference Proceedings. Bali, Indonesia.

[14] Fall, L. T., Kelly, S., MacDonald, P., Primm, C., \& Holmes, W. (2013). Intercultural communication apprehension and emotional intelligence in higher education: Preparing business students for career success. Business Communication Quarterly,.76(4), pp. 412-426.
[15] Gable, S.L \& Haidt, J. (2005). What (and why) is positive psychology? Review of General Psychology, 9, 103-110.

[16] Goleman, D. (1995). Emotional intelligence. New York: Bantam Books.

[17] Goleman, D. (1995). Emotional Intelligence: Why it can matter more than IQ. Britain: Bloomsbury.

[18] Goleman, D. (1998). Working with emotional intelligence. New York: Bantam Books.

[19] Goleman, D., Boyatzis, R., \& McKee, A. (2002). Primal leadership: Realizing the power of emotional intelligence. Boston: Harvard Business School Press.

[20] Gill, V. (2003) "Emotional quotient more important than IQ", The Tribune, No. May 1, pp13.

[21] Ghosh, P. (2003) "Emotionality of intelligence", Everyman's Science, Vol.38, pp2-5.

[22] Grace, A. F. (2012). Emotional Intelligence as Predictors of Academic Achievement among Some University Students in Barbados. International Journal of Higher Education, 1.

[23] Hen, M \& Goroshit, M. (2014). Academic Self-Efficacy, Emotional Intelligence, GPA and Academic Procrastination in Higher Education. Eurasian Journal of Social Sciences, 2:1-10.

[24] Hilaluddin Johan Ariffin. Kepintaran emosi dan kaitannya dengan pencapaian akademik: Satu kajian di Sek.Men.Doktor Burhanuddin, Taiping. Unpublished Master Dissertation, Universiti Utara Malaysia, 2003.

[25] Hong, J. Y. (2012). Why do some beginning teachers leave the school, and others stay? Understanding teacher resilience through psychological lenses. Teachers and Teaching: Theory and Practice, 18(4), 417-440.

[26] Honicke, T \& Broadbent, J. (2016). The influence of academic self-efficacy on academic performance: A systematic review. Education Research Review, 17: 63-84.

[27] Irfan Mushtaq \& Shabana Nawaz Khan. (2012). Factors Affecting Students’ Academic Performance. Global Journal of Management and Business Research, 12(9).

[28] Kamassi, Ahmed \& Manaf, Noor \& Omar, Azura. (2019). The level of Emotional Intelligence among Administrative Staff in Higher Learning Institution. Journal of Economics and Human Development, 10 (2), 324-335. Retrieved Nov 042020 from: https://www.researchgate.net/publication/33 9900736_The_level_of_Emotional_Intelligence_among A dministrative_Staff_in_Higher_Learning_Institution

[29] Khan, A. S., Cansever, Z., Avsar, U. Z., \& Acemoglu, H. (2013). Perceived self-efficacy and academic performance of medical students at Ataturk University, Turkey. Journal of the College of Physicians and Surgeons Pakistan, 23: 495-498.

[30] Koydemir, S., \& Schlutz, A. (2012). Emotional intelligence predicts components of subjective well-being beyond personality: A two-country study using self and informant reports. The Journal of Positive Psychology, 7(2), 107-118.

[31] Kumar, J. A., \& Muniandy, B. (2012). The Influence of Demographic Profiles on Emotional Intelligence: A Study on Polytechnic Lecturers in Malaysia. International online 
journal of educational sciences. 4(1).

[32] Lane, A. M., \& Wilson, M. (2011). Emotions and trait emotional intelligence among ultra-endurance runners. Journal of Science and Medicine in Sport, 14(4), 358-362.

[33] Lin, M.-C., Pan, C.-T., \& Ching, G. S (2015). Common problems and coping solutions of university students in Taiwan. International Journal of Research Studies in Education, 4(1): 3-16.

[34] Low, G.R. (2000). Quantifying Emotional Intelligence: Positive contributions of emotional mind. A paper presented for the Spring 2000 faculty lecture as Texas A\&M University/Kingsville, Kingsville, Texas.

[35] Low, G.R \& Nelson, D.B (2004). Emotional intelligence: Effectively bridging the gap between high scholl and college. Texas Associaltions Of Secondary School Principals (TASSP).

[36] Low, G.R \& Nelson, D.B. (2009). Emotional Intelligence and College Success: A Research-Based Assessment and Intervention Model. Retrieved 12 Dec 2019 from: www.tamuk.edu/.../EI_and_College_Success-2006_cederpa per.pdf.

[37] Maher, J. P., Doerksen, S. E., Elavsky, S., Hyde, A. L., Pincus, A. L., Ram, N., \& Conroy, D. E. (2012). A daily analysis of physical activity and satisfaction with life in emerging adults. Health Psychology, 32(6), 647-656.

[38] Mahmood Nazar Mohamed (1992). Pengantar Psikologi: Satu Pengenalan Asas Kepada Jiwa dan Tingkah Laku Manusia. Kuala Lumpur: Dewan Bahasa dan Pustaka.

[39] Mapfumo, J. S., Chitsiko, N., \& Chireshe, R. (2012). Teaching practice generated stressors and coping mechanisms among student teachers in Zimbabwe. South African Journal of Education, 32(2), 155-166.

[40] Marquez, P.G., Martin, R.P., \& Bracket, M.A. (2006). Relating emotional intelligence to social competence and academic achievement in high school students. Psichotema, 18(Supl.), 18-23.

[41] Mohd Tajuddin Zakaria (1995). Hubungan di antara stail kepimpinan guru besar dengan iklim ekolah dan pencapaian akademik. Unpublished Master Dissertation, Universiti Utara Malaysia.

[42] Mustafa Afifi, Amal Shehata, Enas Mahrous Abd Alaziz. (2016). Emotional Intelligence, Self- Efficacy and Academic Performance among University Students. Journal of Nursing and Health Science (IOSR-JNHS),5(3) :74-81.

[43] Neuville, S., Frenay, M., \& Bourgeois, E. (2007). Task value, self-efficacy and goal orientations: Impact on self-regulated learning, choice and performance among university students. Psychologica Belgica, 47: 95-117.

[44] Ngui, G. K., \& Lay, Y. F. (2020). The effect of emotional intelligence, self-efficacy, subjective well-being and resilience on student teachers' perceived practicum stress: A Malaysian case study. European Journal of Educational Research, 9(1), 277-291. https://doi.org/10.12973/eu-jer.9.1 .277

[45] Norhayati Hj Ahmad Zakaria. Kecerdasan emosi dan hubungannya dengan pencapaian akademik. Unpublished Master Dissertation, Universiti Utara Malaysia, 2003.
[46] Okun, B.F. (2002). Effective helping: Interviewing and counselling Techniques. Canada: Brooks/Cole Thomson Learning.

[47] Pajares, F. (1996). Self-Efficacy Beliefs in Academic Settings. Review of Educational Research, 66: 543.

[48] Pau, AKH., Croucher, R., Sohanpal, R., Muirhead, V., \& Seymour, K. (2004). Emotional Intelligence and Stress Coping in Dental Undergraduates - a Qualitative Study. British Dental Journal, 205-209.

[49] Richardson, M., Abraham, C., and Bond, R. (2012). Psychological correlates of university students' academic performance: a systematic review and meta-analysis. Psychol. Bull, 138:353-387.

[50] Sahinidis, A., Kallivokas, D., Markantonatou, A. \& Sdvolias, L. (2016). Emotional intelligence effects on academic performance. An empirical study of university students, Tourism Research Institute, 15(1): 151-162.

[51] Sajna Jaleel, Alie Molly Verghis, "Comparison between Emotional Intelligence and Aggression among Student Teachers at Secondary Level," Universal Journal of Educational Research, Vol. 5, No. 1, pp. 137 - 140, 2017.

[52] Salami, S. O. (2010). Emotional intelligence, self-efficacy, psychological well-being and students' attitudes: Implications for quality education. European Journal of Educational Studies. 2(3), pp. 247-257.

[53] Salovey, P., \& Mayer, J.D. (1990). Emotional Intelligence. Imagination, cognitition, and personality, 9, 185-211.

[54] alovey, P., Mayer, J.D., Goldman, S.L., Turvey, C. \& Palfai, T.P. (1995). Emotional attention, clarity, and repair: exploring emotional intelligence using the Trait Meta-Mood Scale. In J.W. Pennebaker (Ed.), Emotion, disclosure, and health (pp. 125-154). Washington, DC: American Psychological Association.

[55] Salovey, P., Mayer, J.D. (1997). What is emotional intelligence? In P. Salovey and D. J. Sluyter (EDS), Emotional development and emotional intelligence: educational implications (pp 3-31). New York: Basic Books.

[56] Savas, A. C., Bozgeyik, Y., \& Eser, I. (2014). A study on the relationship between teacher self-efficacy and burnout. European Journal of Educational Research, 3(4), 159-166. https://doi.org/10.12973/eu-jer.3.4.159

[57] Shi, J., \& Wang, L. (2007). Validation of emotional intelligence scale in Chinese university students. Personality and Individual Differences. 43(2), pp. 377-387.

[58] Straub, R.O (2002). Health Psychology. Worth Publisher: New York.

[59] Vela R.H. Jr. (2003). The role of emotional intelligence in the academic achievement of first year college students, Unpublished doctoral dissertations, Texas A\&M University-Kingsville.

[60] Windle, G., Bennett, K. M., \& Noyes, J. (2011). A methodological review of resilience measurement scales. Health and Quality of Life Outcomes, 9(8), 1-18.

Yokoyama, S. (2019). Academic Self-Efficacy and Academic Performance in Online Learning: A Mini Review. Front. Psychol, 9:2794. 